\title{
Review
}

\section{The perpetual immigrant and the limits of Athenian democracy}

\author{
Demetra Kasimis \\ Cambridge University Press, Cambridge, 2018, 206 pp., \\ ISBN: 9781107280571
}

Contemporary Political Theory (2021) 20, S8-S12. https://doi.org/10.1057/s41296-01900349-5; published online 15 October 2019

The nativist sentiments underlying recent chants of 'send her back!' at Trump rallies in July 2019 long predate democracy in America. Demetra Kasimis recounts a similar episode ca. $345 \mathrm{BCE}$ in The Perpetual Immigrant and the Limits of Athenian Democracy. An ordinary citizen, Euxitheus, was accused of hiding his foreign lineage and stripped of his citizenship. Euxitheus was, in Kasimis's words, 'a man known for doing what citizens do' (p. 145): he acted like an Athenian and had no reason to suspect he would be denied the privileges of citizenship. Euxitheus must now defend himself to retain the membership he had always taken for granted. According to Kasimis, this episode illustrates a more general point about membership orders: 'the blood-based division that is supposed to secure equality, mobility, and exceptional standing for the demos also makes it possible to contest the authenticity of a lived practice of membership' (p. 164). Blood trumps deeds and nativism overwhelms the egalitarian promises of democratic governance. Is this unavoidable in democracies, ancient and modern?

Kasimis focuses her book on one particular axis of exclusion in ancient Athens: that of metics (metoikoi). In the first half of the fifth century BCE, Athens' economic growth spurred new waves of immigration, not only from other Greek cities but also from places like Syria, Lydia, and Thrace. During this period, Athens established the institution of metoikia to regulate immigrant membership and restrict the participation of immigrants in civic life. Metics included resident foreigners, manumitted slaves, and their Athenian-born children. By some estimates metics made up anywhere between $20 \%$ and $50 \%$ of the entire free population of Athens. Following Pericles' Citizenship Law in 451/450 BCE, anyone not born of two Athenian parents was a metic. Athens thus disqualified generation after generation from acquiring citizen status on the basis of blood, not place of birth.

The Perpetual Immigrant does not offer a history of metoikia in ancient Athens; instead, it turns to texts by Euripides, Plato, and Demosthenes to illustrate how the

(C) 2019 Springer Nature Limited. 1470-8914 Contemporary Political Theory Vol. 20, S1, S8-S12 
metic functioned as an object of political and theoretical concern in Athenian political thought. The metic, Kasimis argues, provides an important site of 'discursive and political theoretical meaning' (p. 3). Her chosen writers wrestle with democracy's relation to nativism and the ambiguous, paradoxical effects of blood-based membership orders. In the book's most important contribution, Kasimis' readings reveal not only the importance of the metic in these texts but also the degree to which political theorists have missed or ignored the metic as a cynosure for questions of membership, inclusion, exclusion, and democracy in ancient political thought. The Perpetual Immigrant offers cogent evidence against engrained habits of ancient political thought long structured by binaries of freedom/ slavery, citizen/non-citizen, native/barbarian, mass/elite, and male/female. Standing outside these binaries, the figure of the metic forces political theorists to reconsider basic starting assumptions about the formation and maintenance of the political subject and the orders of membership that shape it.

Euripides' Ion, the first of Kasimis's texts, seems to present the founding myth of autochthony. 'Autochthony' names the myth that all Athenians were 'born of the Earth,' as the title of Nicole Loraux's (2000) book puts it, with their blood traceable back to a mythical ancestor named Erechtheus. Yet while the Ion depicts this myth, it also transforms it. When the native-born Ion must return to Athens on the condition of 'passing' as a metic, Kasimis argues, Euripides suggests that the possession of Athenian blood need not entail a lived practice of citizenship, nor that the city must deliver on its guarantee to make good on the democratic promise of equality. The Ion thus illuminates a basic instability about who is a citizen despite the foundational myth of blood-based membership. Autochthony is insufficient for securing the Athenian membership order - although this insufficiency may also open, as I discuss more below, new democratic possibilities.

Kasimis's reading of Euripides' Ion lays the groundwork for a revelatory rereading of Plato's Republic with a metic lens. Although not always with explicit mention, Kasimis builds on research by J. Peter Euben, S. Sara Monoson, Christina Tarnopolsky, Jill Frank, and others (myself included) by placing the Republic within the context of democratic Athens and considering it as a site for reflecting on the preoccupations of that vibrant, restless polis. The Republic calls attention to this context with its first words, in which Socrates describes descending into the Piraeus, the port of Athens that was also the location of much of Athens' immigration and the threshold between native sons and outsiders. The Festival of Bendis that draws Socrates and Glaucon to the Piraeus typified this metic space: the cult of Bendis was brought to Athens by Thracians and although the polis-wide festival was controlled by the Athenian demos, metics shared in the celebration. In more metaphoric terms, the Piraeus was a space of disorder that the argument of the Republic attempts to reorder. The father of the argument, Cephalus embodies the troubling dimensions of the Piraeus: he is a metic, both unaccountable and

(C) 2019 Springer Nature Limited. 1470-8914 Contemporary Political Theory Vol. 20, S1, S8-S12 
powerful due to accrued wealth and influence. His definition of justice sets the terms for the conversation that follows.

Kasimis' reframing of the Republic's 'metic space' foregrounds unheralded yet cogent readings of at least two of the dialogue's central elements: the noble lie and the characterization of democracy. Drawing on material previously published in Contemporary Political Theory (Kasimis, 2016), Kasimis rereads the noble lie as laying bare the artifice by which regimes like Athens produce membership status as a natural or essential category. By revealing the fictional basis of such status, the argument of the Republic 'makes an open secret' of the mechanism by which nature and culture are secured (p. 87). The noble lie is not, in other words, the Machiavellian ruse by which Socrates and his interlocutors benight the citizens of the kallipolis; rather, it describes the constitutive fiction of all membership orders, most pointedly that of Athens.

The discussion of democracy in the eighth book of Plato's Republic is often read as Plato's complaint about the collapse of natural status distinctions, but Kasimis reinterprets this moment in the dialogue as a 'denaturing argument' (p. 23). Instead of lamenting democratic disorder, Kasimis suggests, Socrates and his interlocutors illuminate the artificiality of the natural distinctions and hierarchies upon which democracies rest. Democratic freedom culminates in the imitation (mimesis) of all ideas; democracies thus live on performances of citizenship yet these performances destabilize myths like autochthony by showing the difference between blood and Athenianness.

With its theoretical elaboration of the metic, The Perpetual Immigrant gives readers a functional and useful concept for contemporary political theorizing. Less developed and yet more provocative in Kasimis's account is how her analysis casts in doubt conventional wisdom about the meaning of democracy more generally. Metics could teach Athens about democracy - or teach scholars of democracy. Kasimis hints at this point when she acknowledges that '... Athenian membership rules make free participation in some spaces of civic life an indeterminate index' that allowed 'the passing of metics into the deliberative spaces of political life' ( $\mathrm{p}$. 13). In other words, metics were everywhere and they assumed political power despite its being denied them. Taking Josiah Ober's definition of democracy as 'the capacity of the people to do things' (Ober, 2008, p. 3) you could say that these metics were democratic. Indeed, they were democratic against the confining and confounding institutions of the so-called Athenian democracy.

These suggestions about the generative potential of the metic for theorizing democracy gain traction when considered in light of the facts (and not just the autochthonous legend) of the Athenian democracy's founding. Cleisthenes, the revolutionary leader of the Athenian democracy, was not born of two Athenian parents. His mother, as Herodotus recounts, was the daughter of the tyrant of 
Corinth, also named Cleisthenes (6.131; the story of how Cleisthenes père won his bride is among the most hilarious in the whole of the Histories and well worth reading). Not only did metics pass in the ordinary civic space of Athens' demes: a metic created these demes and by doing so invented some of the most basic and essential democratic institutions in Athens.

Pushing this generative potential of the metic a step or two farther: What is the Piraeus if not the 'undercommons' of the Athenian democracy, the space of improvisation and creativity facilitated and encouraged by the very exclusions claimed as necessary or constitutive of Athenian democracy (Moten and Harney, 2013)? What if the 'metic space' of the Republic does not only seek to 'reorder', in Kasimis's words, the disorder provoked by Cephalus and his metic ilk, but to equip Athenians and non-Athenians with power of self-rule, as Jill Frank (Frank, 2018) has argued, a power necessary for democratic life? The perpetual immigrant of Kasimis' title may presage the potentials - as much of the limits - of Athenian democracy and democracies today.

'What if', Kasimis concludes her book, 'the metic is the critical figure of our time'? (p. 183). Considering her arguments from a twenty-first century context, the critical relevance of the metic seems obvious: all of us live among citizens who do not act like citizens and non-citizens who, in Paul Apostolidis's words, could 'Teach America about Democracy' (Apostolidis, 2010). 'Send her back' stands on American myths of belonging that, when examined, crumble much like autochthony on Kasimis' rereading of the Republic. Whether or not you find the undecidable metic a problem depends on your view of democracy. Kasimis tends to treat membership orders and formal institutions as the whole of democracy, but the moments I've mentioned earlier - the undisciplined freedom of the metic space, the improvisational political activity of metic citizenship - open the possibility that democratic life may be elsewhere. 'Political theory from the edges of Athenian democracy' (p. 168), as Kasimis describes it, need not confine itself to a critical mode. These metics, like today's immigrants, can inspire other political dreams, dreams of what Derrida calls 'a democracy to come'.

\section{References}

Apostolidis, P. (2010) Breaks in the Chain: What Immigrant Workers Can Teach America about Democracy. Minneapolis: University of Minnesota Press.

Frank, J. (2018) Poetic Justice: Rereading Plato's Republic. Chicago: University of Chicago Press.

Kasimis, D. (2016) Plato's Open Secret. Contemporary Political Theory 15(4): 339-357.

Loraux, N. (2000) Born of the Earth: Myth and Politics in Athens., trans. S. Stewart, Ithaca, NY: Cornell University Press.

(C) 2019 Springer Nature Limited. 1470-8914 Contemporary Political Theory Vol. 20, S1, S8-S12 
Moten, F. and Harney, S. (2013) The Undercommons: Fugitive Planning and Black Study. New York: Minor Compositions.

Ober, J. (2008) The Original Meaning of 'Democracy': Capacity to Do Things, Not Majority Rule. Constellations 15(1): 3-9.

Publisher's Note Springer Nature remains neutral with regard to jurisdictional claims in published maps and institutional affiliations.

Joel Alden Schlosser

Bryn Mawr College, Bryn Mawr, PA 19010, USA

jschlosser@brynmawr.edu 